\title{
PENILAIAN KELAYAKAN EKONOMI REDUCING EMISSION FROM DEFORESTATION AND FOREST DEGRADATION (REDD+) (Economic Feasibility of Reducing Emission From Deforestation And Forest Degradation (Redd+)
}

\author{
Oleh/By: \\ Kirsfianti Ginoga ${ }^{1}$, Deden Djaenudin ${ }^{2}$ dan Enik Ekowati ${ }^{3}$ \\ ${ }^{1,2,3}$ Pusat Litbang Perubahan Iklim dan Kebijakan, Jalan Gunung Batu No. 5 Bogor \\ E-mail:kginoga@indo.net.id
}

\begin{abstract}
Economic feasibility is one of the condition needed for REDD+ proponent, as mandated in Ministerial Decree No. P. 30/Menbut-II/2009. This analysis provides economic insight to ensure the viability of REDD+ activity sustainably at particular area. In general, economic feasibility is assessed based on abatement and transaction costs. Abatement costs is a cost for producing uncertified $\mathrm{CO}_{2}$ equivalent that can be estimated by Opportunity Costs (OC) of land use change, while transaction costs is the cost forparticipating in Certified Emission Reductions (CERs).

This paper aims to provide methods for economic analysis, including available instrument to undertake analysis. The result shows application of particular assumption, data, and concept can produced different estimate on price of CERs. Therefore, estimations need to consider several key factors such as potential stakeholders involved, technology, buman resource, and location to avoid over estimate or under estimate of the results.
\end{abstract}

Key words: Economicfeasibility, REDD+, MinisterialDecree No. P. 30/Menbut-II/2009

\begin{abstract}
ABSTRAK
Permenhut No. P. 30/Menhut-II/2009 mensyaratkan perlunya dilakukan kelayakan ekonomi sebagai salah satu aspek yang menentukan penilaian diterima tidaknya permohonan kegiatan REDD + . Hal ini ditujukan untuk memberikan jaminan keberlangsungan kegiatan pengurangan emisi dari deforestasi dan/atau degradasi untuk satuan waktu tertentu pada lokasi yang bersangkutan dan sekitarnya. Secara umum pernilaian kelayakan ekonomi biasanya didekati dari biaya abatasi dan biaya transaksi. Dalam banyak kasus, biaya abatasi adalah biaya untuk memproduksi karbon yang belum bersertifikat dan dapat diestimasi dari biaya kesempatan yang hilang (OCs) dari alternatif peruntukan lahan yang lain, termasuk dalam biaya ini adalah arus nilai sekarang yang hilang, dan biaya/resiko yang timbul akibat kegiatan REDD+. Sedangkan biaya transaksi umumnya diartikan sebagai seluruh ongkos yang timbul untuk mendapatkan Certified Emission Reductions (CERs) atau Sertifikat Penurunan Emisi Kehutanan.

Tulisan ini bertujuan untuk menyajikan berbagai metode perhitungan kelayakan ekonomi bagi pemohon kegiatan REDD+, termasuk instrument analisis yang tersedia untuk melakukan analisis kelayakan. Hasil kajian menunjukkan bahwa berbagai asumsi dan konsep yang berbeda dapat menghasilkan harga pengurangan satu unit emisi yang berbeda, karena itu estimasi perlu mempertimbangkan berbagai faktor kunci seperti stakeholders, teknologi, sumber daya manusia, data dan lokasi, untuk mencegah terjadinya perhitungan yang terlalu tinggi atau rendah.
\end{abstract}

Kata kunci: Hutan Lindung, perambahan hutan, Permenhut No. P. 30/Menhut-II/2009 


\section{PENDAHULUAN}

Menyadari pentingnya peran hutan untuk stabilisasi gas rumah kaca (GRK) di atmosfir dan tingginya laju kehilangan hutan secara global saat ini, merupakan motivasi dasar yang mendorong perlunya mekanisme yang dapat menurunkan emisi dari pencegahan deforestasi hutan. Mekanisme penurunan emisi dari kegiatan pencegahan deforestasi ini masuk ke dalam agenda negosiasi, dalam pertemuan para pihak (Conference of Party, COP) konvensi perubahan iklim ke 11 tahun 2005 di Montreal. Dalam COP 13 bulan Desember 2007 di Bali, cakupan kegiatan diperluas bukan hanya menurunkan emisi melalui pencegahan deforestasi dan degradasi tetapi juga melalui upaya peningkatan cadangan karbon, konservasi, dan sustainabel managemen dari hutan yang kemudian dikenal dengan nama REDD+.

Hal yang menarik dari REDD+ ialah besarnya potensi aliran dana ke negara-negara yang memiliki hutan luas seperti Indonesia dari pelaksanaan kegiatan ini. Secara global, diperkirakan besar pasar karbon untuk REDD+ mencapai 2-31 miliar USD apabila diasumsikan besar potensi penurunan emisi dari REDD sekitar 50\% dari tingkat emisi global saat ini (2.4 Gt CO2 per tahun), dan harga kredit karbon sekitar 7-20 USD per ton Co2 (MoFor, 2008). Potensi pasar karbon untuk REDD+ jauh lebih besar dari pada A/R CDM (0.1 juta USD dari 8000 juta USD total nilai transaksi CDM). Rendahnya nilai transaksi A/R CDM dikarenakan sifat kegiatannya yang tidak permanen, prosedur perolehan sertifikat penurunan emisi (Certified Emission Reductions, CERs) yang panjang dengan biaya transaksi cukup tinggi, sehingga tidak memberikan cukup insentif untuk jual beli di pasar ini (Cacho, et.al., 2008).

Hal itu, dapat menjadi pembelajaran untuk kegiatan REDD+, berbagai tantangan terkait dengan aspek teknis, sosial, ekonomi dan kelembagaan perlu segera diatasi. Salah satu upaya mengatasi tantangan tersebut adalah dengan mengusulkan kegiatan REDD+ sebagaimana disebutkan dalam Permenhut No. P.30/Menhut-II/2009 tentang tata cara pengurangan emisi REDD +. Dalam Permenhut ini REDD +, diartikan sebagai semua upaya pengelolaan hutan dalam rangka atau yang menghasilkan pengurangan penurunan kuantitas tutupan hutan dan pengurangan penurunan stok karbon yang dilakukan melalui berbagai kegiatan. Maksud dan tujuan REDD adalah untuk mengurangi emisi dari deforestasi dan degradasi hutan dan menekan deforestasi dan degradasi hutan dalam rangka memantapkan tata kelola kehutanan untuk mencapai pengelolaan hutan yang berkelanjutan dan meningkatkan kesejahteraan masyarakat. Sebelum ada keputusan internasional ${ }^{1}$ mengenai mekanisme REDD ditingkat internasional, kegiatan REDD dilaksanakan melalui demonstration activity, peningkatan kapasitas dan transfer teknologi, serta dan/atau perdagangan karbon sukarela (Pasal 22, ayat 1).

Bab IV permenhut ini mensyaratkan untuk pelaksanaan REDD diharuskan memenuhi kriteria pemilihan lokasi dan memiliki rencana pelaksanaan REDD+. Dimana kelayakan ekonomi merupakan salah satu aspek yang disyaratkan dan menentukan penilaian diterima tidaknya permohonan kegiatan REDD. Permenhut mengartikan kelayakan ekonomi sebagai estimasi pendapatan dari REDD dan biaya yang diperlukan untuk menjamin terlaksananya pengurangan emisi dari deforestasi dan/atau degradasi hutan jangka panjang pada lokasi yang bersangkutan dan sekitarnya.

${ }^{1}$ Dibawah UNFCCC (United Nation Framework on Climate Change Convention atau konvensi perserikatan bangsabangsa tentang perubahan iklim.

Penilaian Kelayakan Ekonomi Reducing Emission from Deforestation and Forest ...... (Kirsfianti Ginoga et al.) 
Tulisan ini bertujuan untuk menyajikan berbagai metode perhitungan kelayakan ekonomi bagi pemohon kegiatan REDD+, termasuk instrument analisis yang tersedia untuk melakukan analisis kelayakan berdasarkan beberapa kajian yang dilakukan IFCA (MoF, 2008), dan tinjauan pustaka.

\section{METODE PENELITIAN}

\section{A. Pengertian Kelayakan Ekonomi Kegiatan REDD}

Secara umum kelayakan ekonomi ini akan didekati dari biaya abatasi dan biaya transaksi. Biaya abatasi adalah biaya yang dibebankan kepada pelaku/pemilik hutan untuk merubah lahan ke peruntukan lahan yang baru, atau biaya yang dikeluarkan untuk menghasilkan pengurangan emisi/menghasilkan serapan. Sedangkan biaya transaksi (BT) umumnya diartikan sebagai seluruh ongkos yang timbul untuk mendapatkan aset pengurangan emisi dari kegiatan REDD+, yaitu Certified Emission Reductions (CERs).

Suplai CERs tergantung dari berbagai faktor, seperti lokasi, ketersediaan data, kapasitas sumberdaya manusia, dan sumberdaya lain yang tersedia. Dalam Gambar 1 suplai CERs adalah biaya abatasi marjinal kumulatif dari berbagai level kegiatan pengurangan emisi yang feasibel. Kurva Sp adalah tingkat harga untuk mitigasi karbon pada pasar bersaing sempurna, tanpa ada pengaruh biaya transaksi. Apabila pengaruh biaya transaksi positif, tingkat harga untuk mitigasi bergeser ke atas, $S_{A}$ dan menurunkan keseimbangan jumlah CERs dari $Q_{A^{\prime}}$ menjadi $Q_{A}$ sebagaimana dapat dilihat pada Gambar 1.

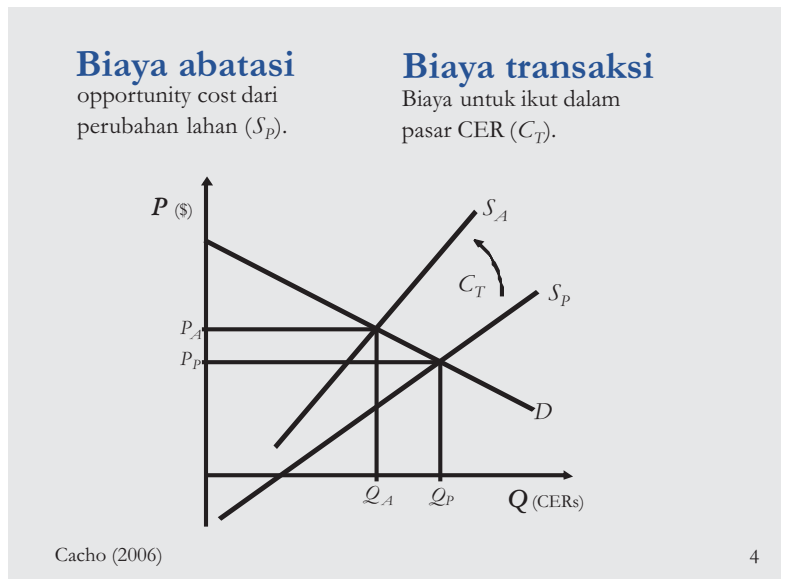

Gambar 1. Pasar CERs (Cacho, et.al., 2008)

Figure 1. CERs Market (Cacho, et.al., 2008)

Dengan persamaan sederhana, kondisi pelaku dapat digambarkan dalam persamaan 1. Pelaku dengan areal $\alpha$ akan berpartisipasi dalam kegiatan REDD bila manfaat yang diterima $\left(v_{c}\right)$ lebih besar dari biaya kesempatan yang hilang $(O C / O C)$ dari alternatif peruntukan lahan yang lain (biaya abatasi, $v_{A}$ ) ditambah biaya transaksi untuk berpartisipasi dalam kegiatan $\operatorname{REDD}\left(v_{T}\right)$, Kondisi dari pelaku adalah sebagai berikut: 


$$
v_{C}>v_{A}+v_{T}
$$

Dimana ketiga variable tersebut dihitung dengan nilai sekarang (present value). Nilai sekarang dari pembayaran karbon yang diterima menjadi:

$$
v_{C}=a \sum_{t} C_{t} p_{F}\left(1+\delta_{s}\right)^{-t}
$$

Dimana

$C_{t}$ adalah estimasi pengurangan emisi karbon per ha dalam tahun $t$,

$p_{F}$ adalah adalah harga karbon pada tingkat pelaku (belum berrsertifikat)

$\delta_{s}$ adalah discount rate.

Sehingga biaya abatasi dari pelaku adalah:

$$
v_{A}=a \sum_{t} R_{t}\left(1+\delta_{s}\right)^{-t}
$$

Dimana $\mathrm{R}_{t}$ adalah $O C$ pada tahun $t$ sebagai alternatif dari peruntukan lain. Sedangkan biaya transaksi pelaku adalah discounted jumlah biaya transaksi tahunan $\left(q_{t}\right)$ :

$$
v_{T}=\sum_{t} q_{t}\left(1+\delta_{s}\right)^{-t}
$$

\section{B. Metode Analisis}

\section{Opportunity costs $(O C)$}

Biaya abatasi untuk pelaku REDD dapat diartikan sebagai biaya untuk menghasilkan satu unit (belum bersertifikat, uncertified) pengurangan emisi karbon atau biaya untuk menghasilkan satu unit karbon biomas (Cacho, et.al., 2008). Dalam banyak kasus, biaya abatasi diestimasi dari biaya kesempatan yang hilang $(O C)$ dari alternatif peruntukan lahan/kegiatan yang lain, atau biaya untuk menghasilkan pengurangan emisi karbon (persamaan 2). Termasuk dalam biaya ini adalah arus nilai sekarang (NPV) yang hilang dan biaya/resiko yang timbul akibat kegiatan REDD.

NPV dalam konsep ini dapat diartikan sebagai nilai sekarang dari arus pendapatan yang ditimbulkan dari investasi kegiatan seperti tertera pada Tabel tersebut. Alasan pemilihan menggunakan nilai sekarang baik biaya maupun manfaat karena investasi berlangsung untuk jangka waktu tertentu dan uang memiliki nilai yang berbeda pada waktu yang berbeda. Nilai uang sekarang lebih tinggi dibandingkan nilai yang sama apabila diterima pada tahun yang akan datang, sehingga perlu dilakukan pendiskontoan. Karena kriteria ini memperhitungkan nilai kini dari uang dengan cara didiskonto, sehingga nilai NPV merupakan patokan para investor untuk menjalankan suatu proyek. dengan menggunakan program EXCEL, dengan tingkat suku bunga. Dari hasil tersebut dapat dihitung biaya biomas karbon yang berhasil dihasilkan atau pengurangan emisi yang dihasilkan.

Penilaian Kelayakan Ekonomi Reducing Emission from Deforestation and Forest ...... (Kirsfianti Ginoga et al.) 


$$
N P V=\sum_{t+1}^{n} \frac{B t-C t}{(1+i)^{t}} \quad \begin{aligned}
& \text { Dimana: } \\
& \text { Bt }=\text { Penerimaan (benefit) pada tahun ke-t } \\
& \mathrm{Ct}=\text { Biaya (cost) pada tahun ke-t } \\
& \mathrm{N}=\text { tahun } \\
& \mathrm{I}=\text { Discount Rate }
\end{aligned}
$$

Selain NPV, indikator kelayakan lainnya adalah Internal Rate of Return (IRR) atau nilai discount rate yang membuat NPV sama dengan nol. IRR adalah tingkat rata-rata keuntungan intern tahunan bagi pelaku yang melakukan investasi dan dinyatakan dalam satuan persen. Rumus yang digunakan dalam menghitung IRR, adalah (Perkins, 1994):

$$
I R R=i+\frac{N P V_{1}}{N P V_{1}-N P V_{3}}\left(i_{2}-i_{1}\right)
$$

Dimana:

$\mathrm{I}_{1}=$ Discount Rate yang menghasilkan NPV positif

$\mathrm{i}_{2}=$ Discount Rate yang menghasilkan NPV negatif

$\mathrm{NPV}_{1}=\mathrm{NPV}$ yang bernilai positif

$\mathrm{NPV}_{2}=\mathrm{NPV}$ yang bernilai negatif

Suatu usaha atau kegiatan investasi dikatakan layak jika IRR lebih besar dari tingkat discount rate yang ditentukan. Sebaliknya, jika nilai IRR lebih kecil dari tingkat discount rate, maka usaha atau kegiatan investasi tersebut tidak layak untuk dijalankan atau dilanjutkan.

Perhitungan yang lain adalah BCR yang merupakan ratio jumlah keuntungan dari suatu proyek terhadap biaya, yang dalam hal ini dipisahkan antara biaya investasi dengan biaya operasionalnya. Secara matematika dapat dijelaskan sebagai berikut (Perkins, 1994):

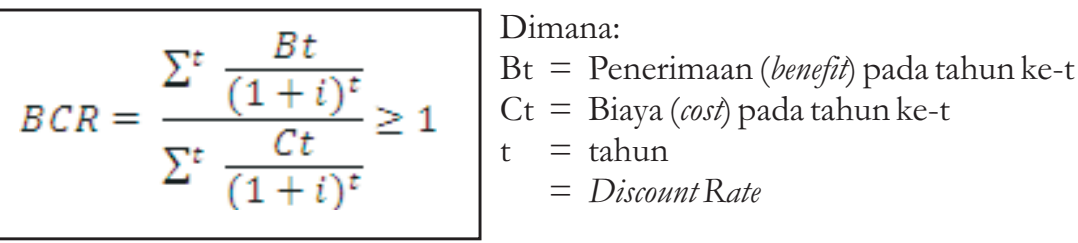

Suatu usaha dinyatakan layak jika Net B/C lebih besar dari satu dan tidak layak jika Net B/C lebih kecil dari satu. Jika Net B/C sama dengan satu, penyerahan keputusan diserahkan kepada pihak manajemen.

Environmental Protection Agency, EPA (2000) menyebutkan bahwa komponen biaya yang dihitung seharusnya melekat pada setiap stakeholder yang terkena dampak dari kegiatan REDD, untuk hutan produksi misalnya, komponen biaya ini akan melekat pada:

(i) Pemerintah (misalnya IIUPH, DR, PSDH, Dana Jaminan Kerja, Dana Investasi),

(ii) pemegang ijin $\mathrm{HPH}$ (misal keuntungan kayu bulat),

(iii) masyarakat (misal gaji dan upah), dan

(iv) industri perkayuan (misal produksi kayu olahan). 
Konsep EPA ini diaplikasikan oleh (Prayitno, 2008). Dengan komponen biaya yang harus diperhitungkan meliputi (Weyant, 1993) antara lain:

(i) pengenaan pajak,

(ii) total biaya langsung,

(iii) berkurangnya GDP, dan

(iv) kompensated variasi pendapatan lain yang berhubungan dengan hilangnya kesempatan pekerjaan dari pemegang ijin dan industri perkayuan.

\section{HASIL DAN PEMBAHASAN}

\section{A. Opportunity Costs (OC)}

Pada tahun 2007, Ministry of Forestry melalui IFCA study melakukan estimasi perhitungan OC dari deforestasi untuk berbagai opsi peruntukan lahan dengan nilai NPV, daur waktu 25-27 tahun dan diskon faktor $10 \%$ (Tabel 1). Dari Tabel 1, terlihat bahwa nilai NPV yang tertinggi adalah untuk kelapa sawit dan hutan tanaman. Insentif dari mekanisme REDD+ harus melebihi nilai OC. Dimana nilai $O C$ untuk timber extraction sebesar US $\$ 450$ per ha, dan nilai break even point sebesar US $\$ 4,09$ per t CO2. Perbedaan nilai sebesar hampir US $\$ 35,91$ per t karbon, antara lain dikarenakan perbedaan konsep biaya yang dinilai sebagai $O C$. Untuk yang pertama, digunakan perhitungan Total OC (TOC) untuk seluruh stakeholder yang terkena dampak dari kegiatan REDD, yang meliputi OC untuk pemerintah, pengusaha hutan, industry dan masyarakat.

Tabel 1. Analisis awal perhitungan $O C$ dan break even point (BEP) untuk berbagai peruntukan lahan

Table 1. OC and breakeven point for several land use

\begin{tabular}{|c|c|c|c|c|c|}
\hline Peruntukan Lahan & $\begin{array}{l}\text { OC dari } \\
\text { deforestasi } \\
\text { (US } \$ / \text { ha) }\end{array}$ & $\begin{array}{l}\text { Tipe } \\
\text { Hutan }\end{array}$ & $\begin{array}{l}\text { Tipe } \\
\text { Tanah }\end{array}$ & $\begin{array}{l}\text { Emisi } \\
(\mathrm{tCO} 2 \mathrm{e})\end{array}$ & $\begin{array}{l}\text { Harga } \\
\text { Break } \\
\text { even } \\
\text { CO2e } \\
(\mathrm{US} \$ / \mathrm{t})\end{array}$ \\
\hline Timber extraction & 450 & Primary & & 110 & 4.09 \\
\hline Timber plantation & 1,073 & Degraded & Mineral & 184 & 5.83 \\
\hline & 399 & Degraded & Peat & 1018 & 0.39 \\
\hline $\begin{array}{l}\text { Timber+Timber } \\
\text { plantation }\end{array}$ & $\begin{array}{l}1,523 \\
849\end{array}$ & $\begin{array}{l}\text { Primary } \\
\text { Primary }\end{array}$ & $\begin{array}{l}\text { Mineral } \\
\text { Peat }\end{array}$ & $\begin{array}{l}661 \\
1385\end{array}$ & $\begin{array}{l}2.30 \\
0.61\end{array}$ \\
\hline Oil palm plantation & $\begin{array}{l}3,963 \\
4,265\end{array}$ & $\begin{array}{l}\text { Degraded } \\
\text { Degraded }\end{array}$ & $\begin{array}{l}\text { Mineral } \\
\text { Peat }\end{array}$ & $\begin{array}{l}184 \\
1018\end{array}$ & $\begin{array}{l}21.54 \\
4.19\end{array}$ \\
\hline $\begin{array}{l}\text { Timber+Oilpalm } \\
\text { plantation }\end{array}$ & $\begin{array}{l}4,413 \\
4,715\end{array}$ & $\begin{array}{l}\text { Primary } \\
\text { Primary }\end{array}$ & $\begin{array}{l}\text { Mineral } \\
\text { Peat }\end{array}$ & $\begin{array}{l}661 \\
1385\end{array}$ & $\begin{array}{l}6.68 \\
3.40\end{array}$ \\
\hline
\end{tabular}

Penilaian Kelayakan Ekonomi Reducing Emission from Deforestation and Forest ...... (Kirsfianti Ginoga et al.) 
Tabel 1. Lanjutan

Table 1. Continued

\begin{tabular}{|c|c|c|c|c|c|}
\hline Peruntukan Lahan & $\begin{array}{l}\text { OC dari } \\
\text { deforestasi } \\
\text { (US } \$ / \text { ha) }\end{array}$ & $\begin{array}{l}\text { Tipe } \\
\text { Hutan }\end{array}$ & $\begin{array}{l}\text { Tipe } \\
\text { Tanah }\end{array}$ & $\begin{array}{l}\text { Emisi } \\
(\mathrm{tCO} 2 \mathrm{e})\end{array}$ & $\begin{array}{l}\text { Harga } \\
\text { Break } \\
\text { even } \\
\text { CO2e } \\
\text { (US } \$ / t)\end{array}$ \\
\hline Rubber & 36 & Degraded & Mineral & 184 & 0.20 \\
\hline Timber + Rubber & 486 & Primary & Mineral & 661 & 0.74 \\
\hline Rice fallow & 26 & Degraded & Mineral & 184 & 0.14 \\
\hline Timber + Rice fallow & 476 & Primary & Mineral & 661 & 0.72 \\
\hline Cassava & 18 & Degraded & Mineral & 184 & 0.10 \\
\hline Timber + Cassava & 468 & Primary & Mineral & 661 & 0.71 \\
\hline
\end{tabular}

Sumber (Sources): MoFor, 2008. IFCA Consolidation Report

Prayitno (2008) mengaplikasikan hasil perhitungan EPA dengan komponen biaya yang dihitung seharusnya melekat pada setiap stakeholder yang terkena impak dari kegiatan REDD. Penelitian yang dilakukan Prayitno di wilayah hutan produksi di Kalimantan (2008) berdasarkan perhitungan nilai shadow price tegakan, yaitu keuntungan yang diperoleh apabila hutan produksi diusahakan sebagai penghasil kayu, meyebutkan bahwa harga karbon adalah sebesar US\$ 40 per ton per tahun. Sehingga, apabila rata-rata kandungan karbon di hutan produksi Kalimantan adalah 119,43 ton C/ ha, besarnya penerimaan yang hilang, apabila akan berpartisipasi dalam REDD adalah Rp 52.553.830,56 per ha per tahun, dimana penerimaan tersebut berasal dari penerimaan yang hilang dari pemerintah Rp 5.945197,87 per ha per tahun (11.3\%), penerimaan pemegang ijin HPH sebesar Rp 223.385,92 per ha per tahun (0.4 \%), industri kayu Rp 37.023.159,61 per ha per tahun (70,4\%), dan penerimaan masyarakat Rp 9.362.087,16 per ha per tahun (17.8 \%). Nilai ini jauh lebih tinggi dari hasil analisis nilai OC pada berbagai peruntukan lahan yang dilakukan oleh tim IFCA.

\section{B. Analisis Biaya Produksi Biomasa Karbon}

Biaya abatasi dapat juga didekati dari biaya untuk memproduksi satu unit biomasa karbon. Untuk mencapai tujuan ini, tahapan pelaksanaan yang akan dilakukan adalah:

1. menghitung besarnya biaya pembangunan hutan, mulai dari kegiatan pembukaan lahan hingga menghasilkan positif pendapatan,

2. menghitung biaya produksi biomasa karbon,

3. membandingkan nilai hutan tanaman tanpa dan dengan karbon.

Analisis biaya pembuatan dan nilai hutan tanaman dilakukan dengan metode Benefit Cost Analysis. Program komputer yang digunakan umumnya software Microsoft Excel. Untuk mengetahui kelayakan usaha REDD dapat dilakukan secara finansial atau ekonomis. Analisis finansial didasarkan pada biaya yang benar-benar dikeluarkan oleh pelaku (harga privat). Sedangkan analisis ekonomi didasarkan pada harga sosial dimana harga telah disesuaikan untuk mengakomodasi distorsi/kebijakan-kebijakan yang menyebabkan ketidaksempurnaan pasar. Kebijakan tersebut misalnya subsidi input/output, tarif, dan kuota. Untuk analisis ini dapat dilihat pada 20 sistem hutan tanaman dan agroforestri pada Cacho et.al (2008), hal. 78. 
Program komputer excel dengan nama MUTAN sudah dibangun untuk mempermudah analisis ini (Lampiran 1).

Dengan konsep ini, Cacho et.al (2008) mengestimasi biaya abatasi untuk berbagai tipe sistem agroforestry yang umum di Sumatra, yaitu karet, kayu manis, damar, dan kelapa sawit sebagaimana terlihat pada Tabel 2. Nilai OC menggambarkan bahwa pemilik lahan tidak akan berpartisipasi dalam pasar CER, kecuali mereka diberikan finansial insentif sebesar OC pada tiap sistem. Nilai biaya abatasi diperoleh dari hasil pembagian biaya OC dengan rata-rata biomasa karbon. Dari Tabel 2 terlihat bahwa biaya untuk menghasilkan biomasa karbon terendah pada sistem damar (US\$ 6,22/tC) dan yang tertinggi adalah kelapa sawit (US\$ $28,48 / \mathrm{tC}$ ). Karena itu, investor yang rasional akan memilih sistem damar, baru kayumanis, karet dan kelapa sawit. Untuk berkompetisi dalam pasar karbon, nilai karbon perlu lebih rendah dari nilai pasar.

Tabel 2. NPV, OC dan biaya abatasi untuk beberapa sistem agroforestry di Sumatera.

Table 2. NPV, OC, and abatement costs for several agroforestry systems in Sumatra

\begin{tabular}{lrrrr}
\hline & Karet & Kayumanis & Damar & Kelapa Sawit \\
\hline Rata-rata biomasa karbon & 21,29 & 11,34 & 51,34 & 13,30 \\
(tC/ha) & & & & \\
NPV* (US \$/ha) & $-94,04$ & 115,32 & $-31,58$ & $-91,31$ \\
OC** (US \$/ha) & 381,54 & 172,18 & 319,08 & 378,81 \\
Biaya Abatasi (US \$/tC) & 17,92 & 15,19 & 6,22 & 28,48 \\
\hline
\end{tabular}

* NPV dihitung untuk periode 70 tahun dengan diskon faktor $20 \%$ dan landproduktivity index 0.5

** Biaya dalam bentuk NPV yang hilang dari merubah peruntukan lahan ubi kayu (US $\$ 287 / \mathrm{ha}$ ) menjadi sistem tersebut.

Berdasarkan tabel penghitungan biaya adaptasi diketahui bahwa sistem kelapa sawit memberikan biaya abatasi tertinggi yaitu 28,84 US\$/tC dimana insentif finansial yang diharapkan oleh pemilik lahan lebih tinggi dari sistem yang lain. Biaya abatai terendah pada sistem damar.

\section{Biaya Transaksi}

Biaya transaksi dapat diartikan sebagai seluruh ongkos yang timbul karena pertukaran (bisnis) dengan pihak lain. Biaya transaksi untuk kegiatan A/R CDM cukup mahal karena banyaknya aktor yang terlibat di dalamnya serta kompleksitas pengaturan dan biaya pengawasan yang ditimbulkan (Ginoga et.al, 2007). Aktor-aktor yang terlibat dalam transaksi meliputi pihak-pihak seperti pengembang proyek, broker, tim verifikasi, pengawas independent serta pihak lain. Kompleksitas pengaturan juga akan berpengaruh terhadap biaya transaksi walaupun menurut aturan tidak ada biaya administrasi pengurusan yang harus dikeluarkan namun biaya dalam rangka konsultasi dan perjalanan dalam kepengurusan. Kemungkinan adanya informasi yang tidak simetris juga dapat melahirkan biaya transaksi yang sangat tinggi yang pada gilirannya akan menghambat pengelolaan hutan yang optimal.

Biaya transaksi meliputi biaya-biaya yang dikeluarkan baik sebelum proyek dimulai maupun setelah proyek berjalan. Perkiraan biaya transaksi sebelum proyek (ex-ante) dan setelah pelaksanaan proyek (ex-post) dapat dilihat pada Tabel 3.

Perhitungan biaya yang terlalu tinggi untuk kegiatan REDD akan mempengaruhi tingkat daya saing, dan kompetisi di pasar CERs. Sebaliknya penilaian yang terlalu rendah

Penilaian Kelayakan Ekonomi Reducing Emission from Deforestation and Forest ...... (Kirsfianti Ginoga et al.) 
akan mengkibatkan kehilangan dan resiko yang cukup besar untuk kelangsungan kegiatan REDD. Karena itu perkiraan biaya untuk meningkatkan daya saing, perlu mempertimbangkan berbagai faktor seperti sistem peruntukan lahan yang paling sesuai untuk lokasi tertentu, teknologi, SDM, dan dengan memasukan seluruh biaya dan manfaat yang ditimbulkan (Ginoga dan Lugina, 2007).

Tabel 3. Perkiraan biaya transaksi untuk REDD+ Table 3. Estimation of transaction costs for REDD+

\begin{tabular}{|c|c|c|}
\hline $\begin{array}{r}\text { Biaya } \\
(\text { Costs }) \\
\end{array}$ & $\begin{array}{l}\text { Penjual } \\
(\text { Seller })\end{array}$ & $\begin{array}{l}\text { Pembeli } \\
\text { (Buyer) }\end{array}$ \\
\hline $\begin{array}{l}\text { Pencarian dan } \\
\text { Negosiasi }\end{array}$ & $\begin{array}{l}\text { Sebelum Pelaksanaan } \\
\text { Membuat rancangan kegiatan, } \\
\text { lokasi, mengikuti sosialisasi/ } \\
\text { informasi, } \\
\text { Menetapkan REL } \\
\text { Memperkirakan potensi pencegahan } \\
\text { emisi karbon } \\
\text { Merancang rencana Manajemen }\end{array}$ & $\begin{array}{l}\text { Pencarian lokasi, kontrak, } \\
\text { Mengadakan pelatihan, } \\
\text { Mengadakan } \\
\text { sosialisasi/informasi }\end{array}$ \\
\hline $\begin{array}{l}\text { Persetujuan, } \\
\text { Registrasi, } \\
\text { Validasi }\end{array}$ & $\begin{array}{l}\text { Persetujuan Propinsi/ Daerah, } \\
\text { Komisi REDD } \\
\text { Lembaga Penilai Independen }\end{array}$ & \\
\hline Manajemen & $\begin{array}{l}\text { Membeli alat dan bahan untuk } \\
\text { pengukuran emisi/serapan karbon } \\
\text { dan sampling ( komputer, } \\
\text { membangun base camp) } \\
\text { Membangun petak ukur permanen } \\
\text { Sesudah Pelaksanaan (MRV) } \\
\text { Membuat database dan administrasi } \\
\text { keuangan } \\
\text { Koordinasi (tingkat lapangan dan ke } \\
\text { tingkat nasional) } \\
\text { Monitoring, reporting }\end{array}$ & $\begin{array}{l}\text { Menghadiri berbagai } \\
\text { pertemuan regular antar } \\
\text { pihak terkait }\end{array}$ \\
\hline
\end{tabular}

Sumber/Sources: Direvisi dari Ginoga dan Lugina (2007).

Pada prinsipnya biaya transaksi yang dibutuhkan adalah biaya transaksi sebelum pelaksanaan dan sesudah pelaksanaan MRV. Biaya transakasi sebelum pelaksanaan meliputi biaya adalah pencarian lokasi dan negoisasi serta proses persetujuan,registrasi, validasi dan manajemen. Biaya transaksi setelah pelaksanaan MRV meliputi membuat database dan administrasi keuangan, koordinasi (tingkat lapangan dan tingkat nasional serta monitoring dan reporting.

Salah satu biaya transaksi yang sangat berpengaruh pada keberhasilan proyek REDD+ adalah biaya pencarian dan negoisasi. Pengembang proyek harus membuat rancangan kegiatan, rencana lokasi proyek dan mencari informasi melalui keikutsertaan dalam sosialisasi REDD+ serta informasi lain. Dalam pencarian lokasi perlu dipastikan status lokasi dan kondisi masyarakat untuk mendukung keberhasilan proyek dimaksud. Terkait hal tersebut diperlukan sosialisasi dan pelatihan kepada masyarakat dengan biaya pelatihan biasanya 
ditanggung oleh pengembang proyek. Dalam hal ini maka biaya transaksi menggunakan modal awal pengembang proyek.

Biaya lain yang dibutuhkan adalah biaya penelitian untuk penetapan Reference Emission Level (REL). Apabila pengembang proyek tidak memiliki tenaga ahli/peneliti maka dibutuhkan konsultan untuk penetapan REL. Salah satu kesulitan dalam penentuan REL adalah ketersediaan data. Apabila pada calon lokasi tidak diperoleh data lengkap maka dibutuhkan biaya untuk mendapatkan data tersebut dengan biaya yang lebih tinggi. Perancangan rencana manajemen dibutuhkan oleh penjual untuk penentuann pengangung jawab kegiatan REDD yang sangat dibutuhkan dalam negoisasi dengan pembeli.

Biaya persetujuan, registrasi, validasi dan manajemen yang menjadi beban pembeli meliputi persetujuan daerah/propinsi dan pusat (komisi REDD). Kelembagaan dan mekanisme registrasi proyek REDD+ belum diatur secara nasional namun dalam kepegurusan/registrasi tidak ada biaya yang harus dibayarkan. Jadi biaya registrasi yang dikeluarkan adalah biaya penyiapan dokumen untuk registrasi, biaya penyiapan dokumen dan biaya konsultasi yang dikeluarkan sampai registrasi proyek REDD+ selesai.

Salah satu biaya terbesar yang harus dikeluarkan oleh pengembang adalah pembelian alat dan bahan untuk pengukuran emisi/serapan karbon dan sampling (komputer, membangun base camp) dan membangun petak ukur permanen. Biaya pembelian alat tergantung dari kebutuhan pengkuran dan tingkat ketelitian yang disesuaikan dengan spesifikasi alat yang dibutuhkan. Untuk pembangunan petak ukur permanen dipengaruhi oleh luasan calon lokasi REDD+. Semakin luas kegiatan proiyek REDD+ maka akan semakin tinggi biaya transaksi yang dibutuhkan. Pada tingkat pembeli maka biaya transaksi yang harus dikeluarkan adalah biaya menghadiri berbagai pertemuan reguler antar pihak terkait.

Biaya transaksi yang dibutuhkan setelah pelaksanaan MRV diantaranya adalah biaya membuat database dan administrasi keuangan. Database ini dibutuhkan untuk memastikan bahwa proyek kegiatan REDD+ memiliki data yangv terukur dengan metode yang dapat dipertanggung jawabkan sehingga akan memudahkan proses verifikasi. Database dibuat simpel namun menggambarkan ketersediaan seluruh data proyek yang dibutuhkan.

Biaya lain yang dibutuhkan adalah biaya koordinasi, monitoring dan reporting. Biaya koordinasi, monitoring dan reporting ini dipengaruhi oleh kemudahan akses lokasi kegiatan proyek REDD+. Semakin jauh dan sulit untuk menjangkau lokasi kegiatan REDD+ maka akan semakin tinggi biaya yang dibutuhkan.

\section{KESIMPULAN DAN SARAN}

Sesuai dengan amanah Permenhut No. P.30/Menhut-II/2009, kelayakan ekonomi sebagai estimasi pendapatan dan biaya kegiatan REDD untuk menjamin kelangsungan pelaksanaanya. Untuk menilai kelayakan ekonomi ada berbagai instrumen yang dapat digunakan yang menilai semua biaya/resiko dan manfaat yang ditimbulkan karena kegiatan REDD+. Paper ini menjelaskan berbagai instrumen dan tahapan yang dapat dilakukan untuk melakukan analisis kelayakan ekonomi tersebut. Beberapa aplikasi dari instrumen perhitungan kelayakan ini juga dibahas dalam tulisan ini. Hasil berbagai aplikasi menunjukkan bahwa peruntukan lahan untuk kelapa sawit menghasilkan biaya abatasi yang paling tinggi dibandingkan dengan peruntukan lahan yang lain, sehingga insentif yang diberikan kepada pemilik lahan untuk berpartisipasi dalam pasar CERs REDD+ juga perlu lebih tinggi.

Penilaian Kelayakan Ekonomi Reducing Emission from Deforestation and Forest ...... (Kirsfianti Ginoga et al.) 


\section{DAFTAR PUSTAKA}

Cacho, O., Hean, R., Ginoga, K.L., Wise, R., Djaenudin, D. Lugina, M., Wulan, Y., Subarudi., Lusiana, B. van Noordwijk, M and Khasanah N. 2008. Economic potential of land use change and forestry for carbon sequestration and poverty reduction. ACIAR technical reports No. 69, $98 \mathrm{pp}$.

Cacho, O., and R. Wise. 2005. Transaction and abatement costs of agroforestry projects for carbon sequestration. A paper presented at SAFOD ICRAF, Malang.

Environmental Protection Agency. 2000. EPA Guidelines for Preparing Economic Analysis. Washington DC.

Ginoga, K.L. dan Mega Lugina. 2007. Biaya transaksi dalam perolehan sertifikat penurunan emisi pembangunan bersih Jurnal Penelitian Sosial dan Ekonomi Kehutanan Vol. 4, No. 1, Maret 2007. ISSN 1829-8109

MoFor. 2008. IFCA 2007 Consolidation Report: Reducing Emission from Deforestation and Degradation in Indonesia. Published by FORDA Indonesia.

Perkins F. 1994. Practical Cost Benefit Analysis. Macmillan Education Australia PTY LTD. Australia.

Prayitno, A. 2008. Estimasi Kandungan dan Harga karbon pada tegakan hutan produksi di Kalimantan. Program Pasca sarjana Universitas Gajah Mada, Yogyakarta.

Weyant, J.P. 1993. Cost of reducing global carbon emission. The Journal of Economic Perspectives, Vol. 74, pp. 27-46. 

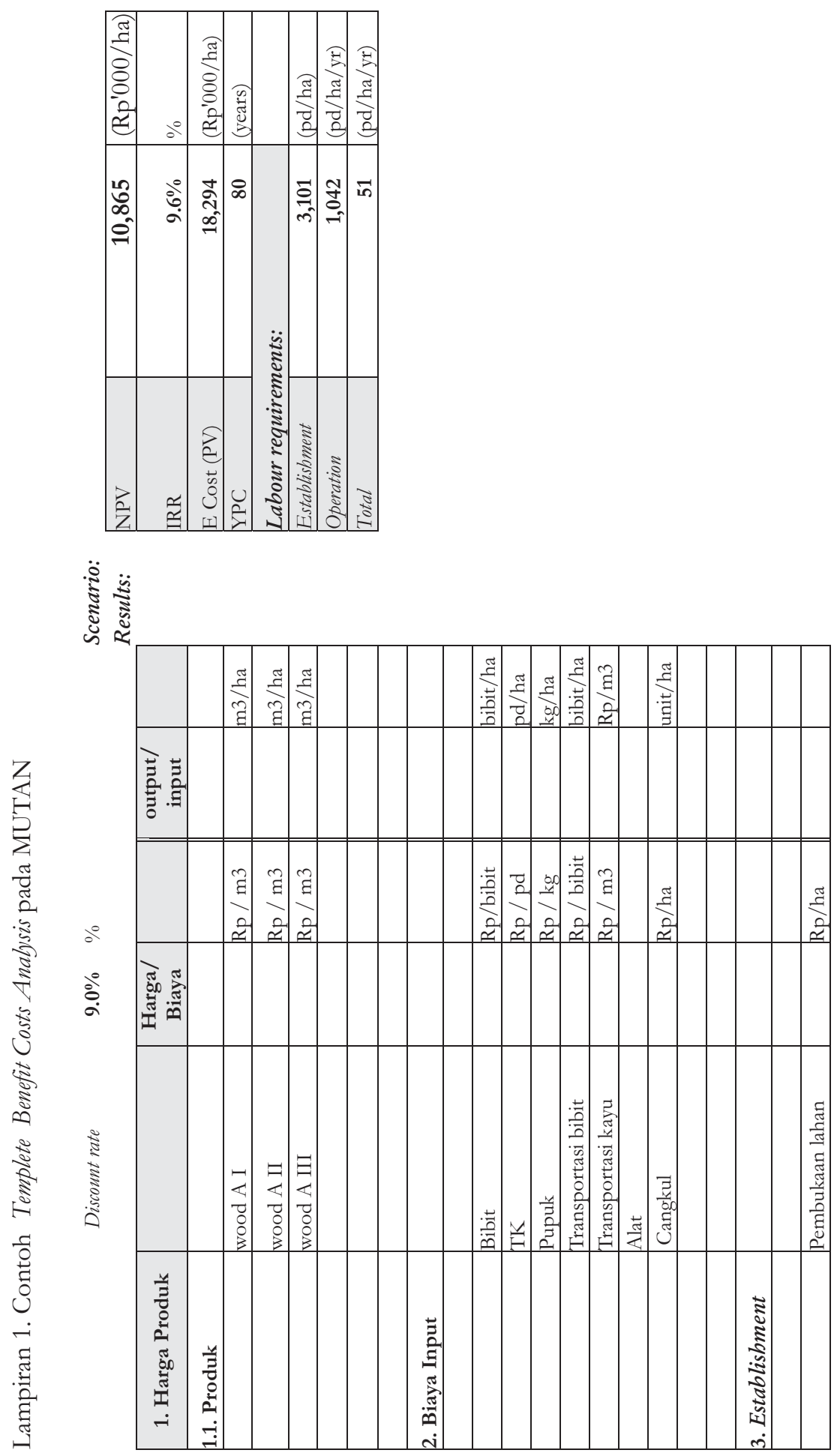

Penilaian Kelayakan Ekonomi Reducing Emission from Deforestation and Forest ...... (Kirsfianti Ginoga et al.) 